\title{
Obecność kapitału zagranicznego w systemie bankowym Rosji
}

\author{
The presence of foreign capital in the banking system of Russia
}

\section{Wprowadzenie}

Federacja Rosyjska jest jednym z największych państw na świecie i jej gospodarka po 1990 r. w coraz większym stopniu zorientowana jest na rynek globalny. W kraju tym znajdują się bardzo duże złóża rzadkich zasobów naturalnych, głównie surowców energetycznych i metali szlachetnych. Produkt krajowy brutto Rosji plasuje ją, w zależności od przyjętej metodyki liczenia, na 10-12 pozycji na świecie. Zrozumiałe jest, że tak duży potencjał gospodarczy wywoływał zainteresowanie o charakterze globalnym, a międzynarodowy kapitał poszukiwał możliwości biznesowych w gospodarce rosyjskiej. Celem artykułu jest zaprezentowanie ewolucji obecności kapitału zagranicznego w systemie bankowym Rosji od początku okresu transformacji systemowej do początku lat 20. XXI w.

\section{Obecność kapitału zagranicznego w rosyjskiej bankowości po $1990 \mathrm{r}$.}

Od początku lat 90. XX w., tj. od rozpoczęcia transformacji gospodarczej w kierunku systemu opartego w większym stopniu na zasadach rynkowych, gospodarka rosyjska była interesującym miejscem lokowania kapitału przez zagranicznych inwestorów, stwarzającym szanse na wysoką efektywność inwestycji i gwarantującym premię za podejmowane ryzyko. Przesłankami takich szans było postępujące urynkowienie rosyjskiej gospodarki, dobra sytuacja 
makroekonomiczna, bogactwo surowców naturalnych, dominacja Federacji Rosyjskiej na światowym rynku surowców energetycznych oraz wysokie rezerwy dewizowe. Pomyślne zmiany w rosyjskiej gospodarce i systemie bankowym po 1990 r. tworzyły korzystny klimat inwestycyjny dla zagranicznych inwestorów. Jednym z ważniejszych kierunków tych działań w Rosji były wówczas inwestycje w rosyjskim sektorze bankowym.

Podstawową formą inwestycji było zaangażowanie w kapitał założycielski banków rosyjskich, tj. przejmowanie własności w funkcjonujących bankach rosyjskich i tworzenie nowych banków. Państwo rosyjskie w całym okresie przemian rynkowych kontrolowało napływ kapitału zagranicznego do bankowości poprzez procedury formalne i jego limitowanie. W rezultacie takiej polityki jego udział nigdy nie przekroczył 28\% kapitałów własnych sektora bankowego ogółem (Żukowska, 2019). Celem kontroli przepływów kapitałowych było ograniczenie napływu kapitału spekulacyjnego liczącego na wysoką dochodowość inwestycji i ochrona rodzimych organizacji kredytowych ${ }^{1}$ w Rosji. Najbardziej wiarygodne światowe instytucje finansowe zachęcano do inwestowania w Rosji.

Rosyjski system bankowy po $1990 \mathrm{r}$. intensywnie się rozwijał. O ile w $1998 \mathrm{r}$. jego aktywa stanowily $30,4 \%$ rosyjskiego PKB, to w 2005 r. było to już 42,5\%. Do 2016 r. aktywa sektora bankowego wzrastały, by osiągnąć poziom 99,9\% PKB. Od tego roku rozpoczął się niewielki spadek, a potem stabilizacja aktywów sektora bankowego w relacji do PKB do poziomu ok. 90\%, np. w styczniu 2020 r. było to $88 \%$. Można to zinterpretować w taki sposób, że w tym okresie rosyjski PKB wzrastał szybciej niż aktywa sektora bankowego (Żukowska, 2019).

Przez wiele lat wielkość kapitału własnego w rosyjskich bankach komercyjnych nie była imponująca z punktu widzenia zarówno skali gospodarki, jak też liczby działających tam banków oraz obsługiwanych klientów. Obecność kapitału zagranicznego w bankowości komercyjnej w Rosji do 2007 r. zaprezentowali Żukowski, Żukowska (2008). Jednocześnie kapitał własny sektora bankowego w całym okresie transformacji systematycznie wzrastał, ale wzrost ten był niższy niż skali działalności bankowej mierzony wielkością aktywów sektora bankowego. Kapitał ten stanowił w połowie 1998 r. 4,6\% PKB, w 2005 r. wzrósł do 5,6\% PKB, a według stanu na 1 stycznia 2020 r. wynosił 10\% PKB (szerzej Żukowska, 2019).

Analizując z kolei udział kapitału własnego w pasywach rosyjskiego sektora bankowego, należy zauważyć, że w połowie 1998 r. (w momencie wybuchu kryzysu bankowego w Rosji) kapitały własne sektora bankowego w relacji do

1 W rosyjskim prawie do banku używa się określenia „bankowa organizacja kredytowa”. Funkcjonują także „niebankowe organizacje kredytowe” zajmujące się najczęściej rozliczeniami pieniężnymi czy obrotem papierami wartościowymi. 
pasywów ogółem wynosiły aż 15,2\%, natomiast pół roku po wybuchu kryzysu (na początku 1999 r.) obniżyły się o połowę (do 7,3\% sumy bilansowej), a następnie dalej się zmniejszały się, by w połowie 1999 r. osiągnąć wielkość 6,7\% sumy bilansowej. W kolejnych latach sektor bankowy rozpoczął powiększanie kapitałów własnych banków w relacji do sumy bilansowej sektora i udział ten wynosił 13,3\% w 2000 r., 11\% na dzień 1 stycznia 2017 r. Na początku 2020 r. kapitały własne stanowiły 11,4\% pasywów sektora bankowego ogółem (Bank Rosji, 2020). Jest to porównywalne z wielkością tego parametru w innych krajach.

Depozyty ludności i przedsiębiorstw w 1999 r. łącznie stanowiły 46,0\% pasywów sektora, w 2000 r. już 55,3\%, a w 2019 r. osiągnęły 64,1\%. Łączna wielkość kredytów udzielonych przez rosyjskie banki to zaledwie 28,1\% aktywów banków ogółem w 1998 r., ale w 2000 r. było to 44,1\%, a w 2019 r. - 51,3\% aktywów. Skala działalności kredytowej banków rosyjskich w ostatnich latach intensywnie wzrasta, głównie za sprawą wzrostu kredytów, w tym dla ludności, która realizuje odłożony popyt na nieruchomości, mieszkania i samochody (szerzej Żukowska, 2019).

Kapitał zagraniczny wykazywał zainteresowanie rosyjską bankowością od początku lat 90. XX w. Inwestorzy zagraniczni silnie zabiegali o dostęp do rosyjskiego rynku usług bankowych. Nie zrażali się nieuporządkowanym prawodawstwem sektora bankowego, niepełną ochroną własności prywatnej, wysokim ryzykiem inwestycji w Rosji, utrudnieniami biurokratycznymi i formalno-prawnymi ze strony banku centralnego i administracji rządowej.

Obecność kapitału zagranicznego w kapitale sektora bankowego kraju o gospodarce przejściowej jest sygnałem o wzroście zaufania do gospodarki kraju ze strony podmiotów zagranicznych, a jednocześnie wyrazem wzrostu zainteresowania rynkiem usług bankowych (Iwanicz-Drozdowska, Bongini, Smaga, Witkowski, 2017)². Jednakże zawsze najważniejsze znaczenie dla decyzji o wejściu kapitału zagranicznego ma oczekiwana stopa zwrotu z inwestycji i szacowana wielkość ryzyka, jakim jest obciążona decyzja o wejściu na zagraniczny, często nieznany rynek. Te dwa czynniki w różny sposób i z różnym natężeniem decydują o podjęciu decyzji inwestycyjnej przez właścicieli kapitału. Władze kraju goszczącego zawsze mają własną politykę wobec kapitału zagranicznego. W zależności od przyjętego kierunku tej polityki muszą określić, czy są zainteresowane obecnością kapitału zagranicznego, i starać się przekonać inwestorów zagranicznych lub też odwrotnie - stwarzać utrudnienia, mnożyć bariery

2 Wpływ kapitału zagranicznego na gospodarkę kraju goszczącego oraz na stabilność jego systemu bankowego opisano w m.in. Iwanicz-Drozdowska, Bongini, Smaga, Witkowski (2017). Publikacja ta zawiera także przegląd literatury anglojęzycznej na ten temat. 
i zwiększać wymagania wobec zagranicznych inwestorów³. W początkowym okresie transformacji rynkowej w Rosji można było zaobserwować nieufność instytucji rządowych i niechęć w stosunku do kapitału zagranicznego. Zapewne powodem była potrzeba kontrolowania jakości napływającego kapitału, brak zaufania do niektórych zagranicznych inwestorów oraz ochrona rynku przed zagraniczną konkurencją.

Bank centralny (Bank Rosji) od początku okresu transformacji rynkowej prowadził politykę bardzo ostrożnego dopuszczania banków z udziałem kapitału zagranicznego na rynek rosyjski. Napływ kapitału zagranicznego do kapitałów banków rosyjskich był silnie kontrolowany i limitowany. Kiedy na początku lat 90. ubiegłego wieku, w okresie dość liberalnej polityki licencyjnej, szybko zwiększała się liczba nowo zakładanych banków krajowych, wśród zainteresowanych działalnością bankową pojawili się pierwsi inwestorzy zagraniczni. Jednakże rząd i bank centralny prowadzili ich surową weryfikację. Zgodnie z legitymacją wynikającą z ustawy o bankach i działalności bankowej w rosyjskich wytycznych dotyczących licencjonowania banków przez całe lata 90. XX w. funkcjonowały w różnej wysokości limity dopuszczalnej obecności kapitału zagranicznego w bankowości rosyjskiej (5\%, 10\%, 12,5\% i 25\%), (Bażan, Masliennikow, 2000). Dodatkowo wymagania przy tworzeniu banku z kapitałem zagranicznym były surowsze niż w sytuacji tworzenia banku krajowego.

Zagraniczne banki działające w tym czasie w Rosji można podzielić na 3 podstawowe grupy:

a) duże banki z Europy Zachodniej i Ameryki Północnej, np. Citigroup, JPMorgan Chase Bank, HSBC Holdings, Deutsche Bank, BNP Paribas, UniCredit Bank, ING Bank;

b) światowe banki średniej wielkości pod względem kapitału i aktywów, m.in. Societe Generale, Credit Suisse Group, Commerzbank, BNP Dresdner Bank, Raiffeisen Bank czy japoński Michinoku Bank;

c) wiodące banki z krajów sąsiadujących z Rosją, czyli z Chin, Turcji, Kazachstanu, Armenii, Uzbekistanu, Iranu i Azerbejdżanu.

Banki z udziałem kapitału zagranicznego trafiały na rosyjski rynek usług bankowych na różne sposoby. W pierwszym okresie poprzez utworzenie przed-

3 Przegląd opracowań z zakresu kapitału zagranicznego na rozwój bankowości zawiera artykuł Bartosika (2010).

${ }_{4}$ Niestety autor cytowanego artykułu nie wspomina o Polsce, gdyż obecność placówek banków z polskim kapitałem w Rosji jest niezauważalna (przedstawicielstwo Banku Gospodarki Żywnościowej S.A. i nieco ponad 10\% udział w kapitale założycielskim Międzynarodowego Banku Współpracy Gospodarczej z siedzibą w Moskwie). 
stawicielstwa, następnie założenie własnego banku-córki lub założenie organizacji kredytowej z udziałem kapitałowym kilku podmiotów zagranicznych, w dalszej kolejności fuzje, obejmowanie udziałów większościowych oraz przejęcia banku z kapitałem rosyjskim (Tschoegl, 2003).

Najstarszy historycznie sposób ekspansji kapitału zagranicznego na rynek rosyjski to uruchomienie przedstawicielstwa banku. Jednostki te ze swojej natury nie mogą prowadzić działalności gospodarczej i są wyłącznie obserwatorami rynku bankowego. Jak wynika $z$ doświadczeń historycznych, po rozpoznaniu rynku krajowego pod kątem możliwości biznesowych w Rosji często następowało przekształcenie przedstawicielstwa w samodzielną jednostkę uprawnioną do prowadzenia działalności bankowej ze $100 \%$ udziałem kapitału banku zagranicznego. Przekształcenie miało charakter formalny, ponieważ z punktu widzenia prawnego było to założenie od podstaw banku komercyjnego związane $\mathrm{z}$ odpowiednią procedurą formalną (Wiernikow, 2002a).

Banki zagraniczne, jak pokazuje praktyka, najbardziej zainteresowane były takimi formami obecności na rynku rosyjskim, które pozwalały im zachować pewną niezależność od władz rosyjskich. Stąd najchętniej deklarowały zamiar otworzenia w Rosji oddziałów banków podporządkowanych centrali zlokalizowanej za granicą Rosji. Znacznie rzadziej odbywało się to poprzez nabywanie znaczących pakietów akcji i udziałów w istniejących bankach bądź tworzenia nowych banków. Jednakże polityka rosyjskich władz nadzorczych związana z dopuszczaniem banków zagranicznych do rynku rosyjskiego oparta była na innych priorytetach. Chociaż przepisy licencyjne uwzględniały możliwości tworzenia oddziałów przez banki-nierezydentów, to organy nadzoru bankowego niechętnie udzielały licencji na taką formę działalności. Banki zagraniczne zachęcano do powoływania samodzielnych podmiotów rosyjskich z kapitałem zagranicznym.

Należy zauważyć, że kilka polskich banków w latach 90. XX w. poszukiwało możliwości wejścia na rynek rosyjski - Bank Gospodarki Żywnościowej S.A., Bank Pekao S.A. czy Bank Handlowy S.A. w Warszawie. Ten ostatni przez wiele lat zabiegał o licencję na otworzenie oddziału banku w Moskwie, kierując się swoimi tradycjami. Bank Handlowy S.A. powstał bowiem w $1870 \mathrm{r}$. na ziemiach polskich na terenie zaboru rosyjskiego i wkrótce (1871 r.) otworzył swój oddział w Sankt Petersburgu. W latach 90. XX w. po kilkuletnich staraniach bank uzyskał prawo uruchomienia oddziału i poczynił przygotowania do powołania placówki operacyjnej. Jednak ten wątpliwy sukces (biorąc pod uwagę intensywność i czas trwania zabiegów o utworzenie oddziału) zbiegł się z przejęciem Banku Handlowego w Polsce przez inwestora zagranicznego (Citigroup). Amerykański właściciel Banku Handlowego S.A. natychmiast zrezygnował z uruchomienia 
oddziału w Moskwie, gdyż w tym okresie Citigroup był już obecny na rosyjskim rynku bankowym. W Moskwie w połowie lat 90. XX w. funkcjonowało także Przedstawicielstwo Banku Gospodarki Żywnościowej S.A.

Omawiając ilościową charakterystykę rosyjskiej bankowości w okresie od 1990 do 2020 r., można dostrzec najpierw ekspansję, a potem stabilizację banków z kapitałem zagranicznym. O ile liczba działających banków rosyjskich w okresie 1997-2020 zmniejszyła się z 2029 do zaledwie 442, to liczba banków z kapitałem zagranicznym zmniejszyła się ze 152 do 133. Jednocześnie banki zagraniczne zwiększyły swoje kapitały własne i skalę działalności na rynku rosyjskim. Prawie połowa banków z kapitałem zagranicznym to banki ze 100\% kapitałem nierezydentów. Jednocześnie 59 banków z kapitałem zagranicznym to podmioty kontrolowane przez kapitał rosyjski z mniejszościowym udziałem inwestorów. Z 13 do 59 wzrosła liczba funkcjonujących organizacji kredytowych ze 100\% udziałem kapitału zagranicznego w kapitale własnym (Bank Rosji, 2020).

Banki zagraniczne na tle rosyjskiego systemu bankowego przedstawiono w tabeli 1.

Tabela 1. Struktura podmiotowa sektora bankowego Rosji z uwzględnieniem podmiotów z kapitałem zagranicznym (stan na 1 stycznia)

\begin{tabular}{|c|c|c|c|c|c|c|c|c|c|c|c|c|c|c|}
\hline & ڤે & $\stackrel{\infty}{\curvearrowright}$ & Әे & ఠ్ & ڤ్సి & $\stackrel{\text { ?n }}{\stackrel{8}{\circ}}$ & ڤ્ণે & ஓे & $\overrightarrow{\vec{d}}$ & $\stackrel{n}{\stackrel{\sim}{\sim}}$ & $\frac{\operatorname{cn}}{\stackrel{\sim}{\sim}}$ & 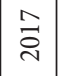 & $\stackrel{\curvearrowright}{\vec{\nu}}$ & ठั̊ \\
\hline $\begin{array}{l}\text { Liczba działających } \\
\text { organizacji kredyto- } \\
\text { wych ogółem }\end{array}$ & 2029 & 1697 & 1476 & 1311 & 329 & 1299 & 1189 & 1108 & 1012 & 956 & 834 & 623 & 484 & 442 \\
\hline $\begin{array}{l}\text { Działające orga- } \\
\text { nizacje kredytowe } \\
\text { z udziałem kapitału } \\
\text { zagranicznego } \\
\text { w kapitale własnym } \\
\text { ogółem, } \\
\text { z tego: }\end{array}$ & \begin{tabular}{|l|}
152 \\
\end{tabular} & 145 & 142 & 130 & 126 & 131 & 153 & 221 & 220 & 246 & 225 & 174 & 141 & 133 \\
\hline $\begin{array}{l}\text {-ze } 100 \% \text { udziałem } \\
\text { kapitału zagranicz- } \\
\text { nego }\end{array}$ & 13 & 16 & 18 & 22 & 27 & 33 & 52 & 76 & 80 & 73 & 75 & 67 & 61 & 59 \\
\hline $\begin{array}{l}\text { - z udziałem od 50\% } \\
\text { do mniej niż 100\% } \\
\text { kapitału zagranicz- } \\
\text { nego }\end{array}$ & 10 & 10 & 12 & 11 & 10 & 9 & 13 & 25 & 31 & 44 & 38 & 25 & 16 & 15 \\
\hline $\begin{array}{l}\text { - z udziałem do } 50 \% \\
\text { kapitału zagranicz- } \\
\text { nego }\end{array}$ & 129 & 119 & 112 & 97 & 89 & 89 & 88 & 120 & 109 & 129 & 112 & 82 & 64 & 59 \\
\hline
\end{tabular}

Źródło: Biuletien Bankovskoj Statystiki, 1998-2020; Bank Rosji, 2004 oraz Bank Rosji, 2019b. 
Obecność kapitału zagranicznego w bankowości krajowej należy rozpatrywać poprzez analizę większej liczby parametrów pokazujących banki z kapitałem zagranicznym na tle całego systemu bankowego. Zaangażowanie banków zagranicznych w Rosji w wybranych latach okresu 1998-2019 wyrażają wybrane wskaźniki zaprezentowane w tabeli 2.

Tabela 2. Wybrane wskaźniki działalności banków z udziałem kapitału zagranicznego na tle wszystkich działających organizacji kredytowych (udział \% stan na 1 stycznia)

\begin{tabular}{|c|c|c|c|c|c|c|c|c|c|c|c|c|}
\hline & 1998 & 2000 & 2001 & 2003 & 2005 & 2007 & 2009 & 2011 & 2013 & 2015 & 2017 & 2019 \\
\hline \multicolumn{13}{|c|}{ Banki z udziałem powyżej 50\% kapitału zagranicznego w kapitałach własnych } \\
\hline Aktywa & 6,7 & 10,8 & 9,5 & 8,1 & 7,6 & 12,1 & 18,7 & 18,0 & 17,8 & 13,9 & 12,7 & 9,6 \\
\hline $\begin{array}{l}\text { Kapitały (fundusze) } \\
\text { własne }\end{array}$ & 5,0 & 10,3 & 9,4 & 7,1 & 7,8 & 12,7 & 17,3 & 19,1 & 19,3 & 17,2 & 16,1 & 13,4 \\
\hline $\begin{array}{l}\text { Środki na rachunkach } \\
\text { w bankach-nierezy- } \\
\text { dentach }\end{array}$ & 6,4 & 9,9 & 15,6 & 22,9 & 14,0 & 23,1 & 17,0 & 20,3 & 21,7 & 15,4 & 18,5 & 13,2 \\
\hline $\begin{array}{l}\text { Kredyty udzielone } \\
\text { podmiotom niefinan- } \\
\text { sowym }\end{array}$ & 8,8 & 9,8 & 7,1 & 7,1 & 6,2 & 10,0 & 16,6 & 15,1 & 14,2 & 11,6 & 9,9 & 6,6 \\
\hline $\begin{array}{l}\text { Kredyty udzielone } \\
\text { osobom fizycznym }\end{array}$ & b.d. & b.d. & b.d. & b.d. & b.d. & b.d. & b.d. & 25,7 & 22,6 & 18,6 & 14,5 & 12,6 \\
\hline $\begin{array}{l}\text { Kredyty udzielone } \\
\text { bankom i depozyty } \\
\text { złożone w bankach }\end{array}$ & 14,6 & 31,8 & 33,0 & 25,9 & 15,8 & 22,5 & 25,0 & 25,1 & 27,3 & 14,1 & 18,8 & 15,5 \\
\hline $\begin{array}{l}\text { Depozyty przyjęte od } \\
\text { osób fizycznych }\end{array}$ & 0,7 & 1,8 & 1,8 & 2,2 & 2,9 & 6,2 & 10,3 & 11,5 & 13,5 & 12,0 & 12,8 & 8,8 \\
\hline $\begin{array}{l}\text { Środki pieniężne przy- } \\
\text { jęte od przedsiębiorstw } \\
\text { i organizacji }\end{array}$ & 7,1 & 14,7 & 14,0 & 10,4 & 9,4 & 13,3 & 18,8 & 17,6 & 18,6 & 14,0 & 12,1 & 10,4 \\
\hline $\begin{array}{l}\text { Udział w zysku sektora } \\
\text { bankowego }\end{array}$ & b.d. & b.d. & b.d. & b.d. & b.d. & b.d. & 19,7 & 20,7 & 19,6 & 20,2 & 15,1 & 13,4 \\
\hline $\begin{array}{l}\text { Liczba organizacji } \\
\text { kredytowych }\end{array}$ & 10 & 12 & 11 & 10 & 9 & 13 & 25 & 31 & 44 & 38 & 25 & 16 \\
\hline \multicolumn{13}{|c|}{ W tym: banki ze $100 \%$ udziałem kapitału zagranicznego } \\
\hline Aktywa & 4,7 & 6,0 & 5,1 & 5,6 & 5,9 & 9,0 & 13,0 & 11,0 & 9,8 & 8,5 & 6,3 & 6,2 \\
\hline $\begin{array}{l}\text { Kapitały (fundusze) } \\
\text { własne }\end{array}$ & 3,4 & 6,2 & 6,2 & 5,4 & 6,3 & 10,1 & 12,2 & 12,1 & 11,4 & 10,9 & 9,4 & 9,6 \\
\hline $\begin{array}{l}\text { Środki na rachunkach } \\
\text { w bankach-nierezy- } \\
\text { dentach }\end{array}$ & 3,2 & 4,2 & 9,0 & 19,2 & 7,7 & 8,2 & 12,1 & 9,2 & 15,2 & 12,0 & 14,4 & 12,1 \\
\hline $\begin{array}{l}\text { Kredyty udzielone } \\
\text { podmiotom niefinan- } \\
\text { sowym }\end{array}$ & 6,9 & 7,6 & 5,5 & 5,5 & 4,6 & 7,9 & 11,6 & 9,2 & 7,5 & 7,8 & 4,6 & 4,8 \\
\hline
\end{tabular}




\begin{tabular}{|l|c|c|c|c|c|c|c|c|c|c|c|c|}
\hline & 1998 & 2000 & 2001 & 2003 & 2005 & 2007 & 2009 & 2011 & 2013 & 2015 & 2017 & 2019 \\
\hline $\begin{array}{l}\text { Kredyty udzielone } \\
\text { osobom fizycznym }\end{array}$ & b.d. & b.d. & b.d. & b.d. & b.d. & b.d. & b.d. & 14,9 & 11,1 & 10,1 & 8,4 & 8,1 \\
\hline $\begin{array}{l}\text { Kredyty udzielone } \\
\text { bankom i depozyty } \\
\text { złożone w bankach }\end{array}$ & 8,4 & 13,0 & 13,2 & 16,3 & 11,4 & 18,4 & 21,6 & 20,0 & 20,0 & 11,1 & 9,3 & 10,4 \\
\hline $\begin{array}{l}\text { Przyjęte depozyty od } \\
\text { osób fizycznych }\end{array}$ & 0,2 & 0,7 & 1,0 & 1,5 & 2,4 & 4,1 & 5,4 & 5,3 & 6,1 & 5,8 & 5,0 & 5,0 \\
\hline $\begin{array}{l}\text { Srodki pieniężne przy- } \\
\text { jęte od przedsiębiorstw } \\
\text { i organizacji }\end{array}$ & 3,3 & 6,5 & 5,5 & 5,5 & 6,6 & 8,9 & 12,6 & 11,0 & 11,0 & 9,9 & 6,7 & 7,5 \\
\hline $\begin{array}{l}\text { Udział w zysku sektora } \\
\text { bankowego }\end{array}$ & b.d. & b.d. & b.d. & b.d. & b.d. & b.d. & 14,8 & 15,1 & 13,4 & 14,9 & 14,9 & 10,3 \\
\hline $\begin{array}{l}\text { Liczba organizacji } \\
\text { kredytowych (szt.) }\end{array}$ & 16 & 20 & 22 & 27 & 33 & 52 & 76 & 80 & 73 & 75 & 67 & 61 \\
\hline
\end{tabular}

Źródło: Bank Rosji, 2003 oraz Bank Rosji, 2005-2019.

Oceniając współczesną rolę i znaczenie kapitału zagranicznego w rosyjskim systemie bankowym obecnie, należy prześledzić zachodzące zmiany w aspekcie historycznym. Pozwoli to dostrzec ewolucję polityki władz Rosji polegającą na stopniowym łagodzeniu zasad, jakie obowiązywały inwestorów zagranicznych wchodzących na rosyjski rynek bankowy w okresie transformacji po $1990 \mathrm{r}$.

Pierwsze działania związane $\mathrm{z}$ dopuszczeniem na rosyjski rynek finansowy inwestorów z zagranicy miały miejsce pod koniec lat 80 . ubiegłego wieku. Jednak dopiero po 1990 r. rynek rosyjski zaczął się szerzej otwierać. W 1997 r. udział kapitału zagranicznego w kapitale systemu bankowego Federacji Rosyjskiej wynosił 5,95\%, natomiast kryzys bankowy 1998 r. doprowadził do drastycznego obniżenia kapitałów własnych rosyjskich banków i w efekcie w 1999 r. udział kapitału zagranicznego automatycznie zwiększył się do 13,52\% kapitału systemu bankowego ogółem. W kolejnych latach udział ten obniżał się, nie w wyrażeniu bezwzględnym, ale dlatego, że banki rosyjskie systematycznie zwiększały swoje kapitały własne.

Na początku 2000 r. udział kapitału zagranicznego w kapitałach rosyjskich banków wynosił nieco ponad 10\%. W Federacji Rosyjskiej działało wówczas 20 organizacji kredytowych ze 100\% udziałem nierezydentów, w 38 podmiotach kapitał zagraniczny obejmował od 20 do 99\% kapitału zakładowego, w 30 organizacjach kredytowych od 1 do 19,99\%, a w 45 organizacjach kredytowych kapitał zagraniczny objął mniej niż 1\% kapitału założycielskiego. Spośród 133 działających organizacji kredytowych z udziałem nierezydentów aż 95 prowadziło działalność w okręgu centralnym, z tego 89 w Moskwie (Bank Rosji, 2001). 
W 2001 r. zarejestrowanych już było 175 banków z udziałem kapitału zagranicznego, z czego 129 banków prowadziło działalność operacyjną. Wśród nich 23 to banki ze $100 \%$ udziałem nierezydentów, 32 z udziałem od 20 do $100 \%$, $31 \mathrm{z}$ udziałem od 1 do $20 \%$ i $43 \mathrm{z}$ udziałem kapitału nierezydentów poniżej $1 \%$. Tak więc banki z udziałem kapitału zagranicznego to niespełna 10\% wszystkich banków działających w Federacji Rosyjskiej w 2001 r. Udział banków zdominowanych przez nierezydentów w aktywach sektora bankowego dochodził do $10 \%$, podobnie kształtował się udział w zyskach sektora banków komercyjnych (Wiernikow, 2002b).

Banków kontrolowanych przez kapitał zagraniczny (z więcej niż 50\% udziałem nierezydentów) na koniec 2002 r. było łącznie 35, ze 100\% kapitału zagranicznego zaś 27. Spośród 1329 działających banków w Rosji w 2003 r. kapitał zagraniczny w ponad 50\% zaangażowany był tylko w 37 bankach, 27 organizacji kredytowych zaś było w 100\% własnością nierezydentów (Lepietikow, 2004).

W 2004 r. kapitał nierezydentów w sektorze bankowym zwiększył się z 18,9 do 23,6 mld rubli, tj. o 24,9\%. Jednak udział nierezydentów w łącznym kapitale własnym sektora bankowego wyniósł na początku 2005 r. zaledwie 6,2\%, zatem był niższy niż w roku poprzednim. Spośród 131 działających organizacji kredytowych z udziałem kapitału nierezydentów w 2004 r. w 42 kapitał nierezydentów wynosił ponad 50\%, a w 33 bankach 100\%. O ile kapitały własne banków rosyjskich w 2005 r. zwiększyły się o 16,8\% w porównaniu ze stanem sprzed roku, to w bankach $\mathrm{z}$ udziałem kapitału zagranicznego w tym okresie wzrosły one prawie trzykrotnie. W rezultacie tego znaczącego wzrostu udział banków z kapitałem zagranicznym w kapitale banków komercyjnych ogółem zwiększył się w 2005 r. z 6,19\% do 11,15\%.

Tendencja wzrostu kapitalizacji banków z udziałem kapitału nierezydentów umocniła się w 2006, a następnie w 2007 r. W połowie 2006 r. udział kapitału zagranicznego w rosyjskim systemie bankowym wynosił już 15,9\% kapitału sektora ogółem. W połowie 2007 r. udział kapitału zagranicznego w kapitale założycielskim rosyjskich banków wyniósł 19\%, a na początku 2008 r. - 25,0\% (tabela 3). Tylko w okresie pierwszych 6 miesięcy 2007 r. inwestorzy zagraniczni zainwestowali w rosyjskim systemie bankowym ponad 2 mld USD. O ile na dzień 1 stycznia 2007 r. kapitał zagraniczny w kapitale założycielskim rosyjskich banków wynosił 90 mld rubli (ok. 4 mld USD), to w połowie tego roku wyniósł prawie 150 mld rubli (ponad 6 mld USD) (Żukowska, 2019).

Inwestycje zagraniczne w sektor bankowy pod koniec XX w. były ograniczane przez władze nadzorcze, a procedury związane z dopuszczeniem kapitału zagranicznego do bankowości były o wiele bardziej skomplikowane niż stoso- 
wane w odniesieniu do inwestorów krajowych. W konsekwencji takiej polityki licencyjnej w początkowym okresie transformacji banki z udziałem kapitału zagranicznego nie zdobyły wiodącej pozycji w systemie pośrednictwa finansowego w Rosji, lecz plasowały się na niszach rynkowych „niezajętych” przez rodzime instytucje finansowe.

W styczniu 2008 r. w Rosji funkcjonowało 86 organizacji kredytowych z ponad 50\% udziałem kapitału zagranicznego w kapitale własnym sektora bankowego oraz 63 organizacje ze 100\% udziałem kapitału zagranicznego (Bank Rosji, 2008). Wśród operacji aktywnych tych banków wzrósł udział kredytów dla rosyjskich organizacji kredytowych (z 15,8\% w 2005 r. do 22,2\% w 2008 r.). Banki z udziałem kapitału zagranicznego zwiększyły swoją aktywność także na rynku depozytów. Wkłady pozyskane od osób fizycznych na początek $2008 \mathrm{r}$. wynosiły 8,9\% depozytów ogółem. Jeszcze trzy lata wstecz bankom z kapitałem zagranicznym osoby fizyczne powierzyły zaledwie 2,3\% oszczędności ulokowanych ogółem w bankach. Banki-nierezydenci osiągały w tym czasie coraz lepsze wyniki finansowe. Jeżeli w 2005 r. wygospodarowały 7,6\% zysków całego sektora bankowego, to na początek 2008 r. było to już 16,4\%. Znaczący jest udział tych banków na rynku papierów wartościowych. Inwestycje w papiery wartościowe (banków i przedsiębiorstw) wynosiły w styczniu 2005 r. 15,7\% aktywów tych banków. Zmniejszają one natomiast zaangażowanie w rządowe papiery wartościowe (Bank Rosji, 2005). Wynika to z pogarszającej się ich opłacalności.

Gros organizacji kredytowych z udziałem kapitału nierezydentów zawsze zlokalizowana była w Moskwie i okręgu moskiewskim oraz część w Sankt Petersburgu. Spośród 136 organizacji kredytowych na początku 2006 r. 88 działało w Moskwie i okręgu moskiewskim, 8 w Sankt Petersburgu, po 3 banki w regionach Omskim, Tiumeńskim i Czelabińskim, a w pozostałych funkcjonowało nie więcej niż 2 banki (Bank Rosji, 2006).

W styczniu 2009 r. kapitał zagraniczny obejmował 28,5\% kapitału rosyjskiego systemu bankowego ogółem. Był to najwyższy udział tego kapitału w bankowości w całym okresie rosyjskiej transformacji. Banki z kapitałem zagranicznym lokowały się w Rosji, wychodząc naprzeciw potrzebom przedsiębiorstw - swoich klientów, które realizowały własne inwestycje w transformującej się rosyjskiej gospodarce.

Kryzys finansowy 2008 r. zatrzymał ekspansję kapitału zagranicznego na rozwijających się rynkach, także w rosyjskiej bankowości. Analiza danych w tabeli 3 wskazuje na niewielki spadek zaangażowania zagranicznych inwestorów w 2010 r., ale odnotować należy utrzymujący się prawie 25\% udział kapitału zagranicznego w rosyjskiej bankowości w latach 2010-2013. Należy podkreślić, że 
ekspansja kapitału zagranicznego do rosyjskiej bankowości do 2009 r. sprzyjała budowaniu konkurencyjnego rynku usług bankowych i poprawie jego stabilności. W tym okresie panowało przekonanie, że obecność banków z udziałem kapitału zagranicznego dobrze służy rozwojowi systemów bankowych i zabezpiecza na wypadek ewentualnych problemów finansowych (Iwanicz-Drozdowska i in., 2017). Jednakże banki zagraniczne stanowiąc silną konkurencję dla rodzimych banków, w dalszym ciągu nie były „dobrze widziane” na rosyjskim rynku usług bankowych.

W styczniu 2013 r. udział kapitału zagranicznego w rosyjskim systemie bankowym wynosił 26,1\%, a w styczniu 2014 r. już tylko 16,1\% mimo wzrostu wartości zaangażowanego kapitału zagranicznego. W tym okresie bowiem banki rosyjskie intensywnie powiększały swoje kapitały własne, przez co obniżał się udział kapitałów zagranicznych w kapitale sektora bankowego ogółem.

Wskaźnik zaangażowania kapitału zagranicznego w rosyjskiej bankowości był w 2013 (26,1\%) i 2014 r. (16,1\%) stosunkowo niski - w porównaniu z innymi krajami Europy Środkowej i Wschodniej. Jak podają specjaliści (Iwanicz-Drozdowska i in., 2017), w tym samym czasie w 15 krajach tego regionu udział kapitału zagranicznego w systemach bankowych wynosił ponad 50\% (np. Estonia 95\%, Albania - 94\%, Litwa - 92\%, Czechy - 91\%, Rumunia i Chorwacja - 90\%, Czarnogóra - 89\%, Bośnia i Hercegowina - 86\%, Słowacja - 84\%, Mołdawia, Serbia i Bułgaria - nieco ponad 70\%). Na 20 analizowanych krajów Europy Środkowo-Wschodniej najniższy wskaźnik zaangażowania kapitału zagranicznego w bankowości wykazywała Ukraina - 28\%.

Od 2015 r. kapitały własne banków z udziałem kapitału zagranicznego w Rosji stabilizują się na poziomie ok. 400 mld rubli i już się nie powiększają. Od 2014 r. dokonuje się koncentracja kapitału własnego banków zagranicznych w coraz mniejszej liczbie banków. O ile w 2014 r. funkcjonowało 251 banków z kapitałem zagranicznym, to w kolejnych latach liczba ta ulega zmniejszeniu do $141 \mathrm{w} 2019 \mathrm{r}$. i 133 w styczniu 2020 r. (Bank Rosji, 2020). Tempo wzrostu kapitału zagranicznego w rosyjskiej bankowości jest niższe niż tempo wzrostu kapitałów własnych ogółem. Od 2007 do 2020 r. kapitał własny sektora bankowego powiększył się ponad 5-krotnie (509\%), a kapitał zagraniczny powiększył się tylko o 445\%. Od 2014 r. zmniejsza się udział kapitału zagranicznego w kapitale własnym sektora jako całości, spada też liczba działających banków z kapitałem zagranicznym. Jednocześnie banki z kapitałem zagranicznym umacniają swoją pozycję w rosyjskim systemie bankowym, o czym świadczy wzrost skali ich działalności i wysoka wiarygodność tych banków (Bank Rosji, 2019a). 
Według stanu na 1 stycznia 2019 r. na rosyjskim rynku usług bankowych obecnych było 141 (na 484 ogółem) organizacji kredytowych z udziałem kapitału zagranicznego. Inwestycje nierezydentów w kapitał własny działających organizacji kredytowych osiągnęły wartość 391 mld rubli i w porównaniu z 1 stycznia 2018 r. nieznacznie (o 2,9\%) spadły z powodu zmniejszenia się udziału nierezydentów w kapitałach własnych 33 banków poprzez wycofanie się zagranicznych akcjonariuszy i w wyniku pozbawienia licencji na realizację operacji bankowych 8 organizacji kredytowych z udziałem nierezydentów. Jednocześnie zwiększyły się inwestycje nierezydentów w udziały 5 banków rosyjskiego sektora bankowego i objęcie akcji 10 banków rosyjskich. Udział nierezydentów w kapitale własnym rosyjskiego sektora bankowego na 1 stycznia 2019 r. liczony według zasad określonych w ustawie O bankach i działalności bankowej z 1990 r. stanowił 12,4\%. W 61 organizacjach kredytowych (56 banków i 5 niebankowych organizacjach kredytowych) udział kapitału zagranicznego wynosił $100 \%$. W porównaniu $\mathrm{z}$ analogicznym okresem $2018 \mathrm{r}$. liczba ta zmniejszyła się o 4 organizacje. W 16 organizacjach kredytowych (15 banków i 1 niebankowa organizacja kredytowa) kapitał zagraniczny obejmował ponad 50\%, ale mniej niż 100\% kapitałów własnych. W porównaniu ze styczniem $2018 \mathrm{r}$. liczba organizacji kredytowych z kapitałem zagranicznym zmniejszyła się o 3 podmioty (Bank Rosji, 2019a), a tylko w okresie 2019 r. spadła o kolejne 8 jednostek (Bank Rosji, 2020).

Bank Rosji w systematycznie publikowanej Informacji o kapitale zagranicznym $w$ rosyjskim systemie bankowym, prezentując dane o krajach pochodzenia kapitału zagranicznego w sektorze bankowym w Rosji, informuje, że w 2019 r. kapitał ten pochodził z takich krajów jak: Chiny (6 banków), Wielka Brytania (3 banki), USA (4 banki), Włochy (2 banki), Szwajcaria (2 banki), Francja (5 banków), Holandia (7 banków), Austria (3 banki), Turcja (4 banki), Niemcy ( 6 banków), Kazachstan (2 banki), Korea (2 banki), Japonia ( 4 banki), Cypr (3 banki), Szwecja, Hiszpania, Singapur, Uzbekistan, Luksemburg, Azerbejdżan, Dania, Czechy, Indie, Iran, Izrael, Polska i inne po jednej organizacji kredytowej (Bank Rosji, 2019a).

Rosnące zainteresowanie rosyjskim rynkiem bankowym międzynarodowych instytucji finansowych (w tym także znaczących) w pierwszej dekadzie XXI w. było dowodem wzrastającego zaufania do rosyjskiego systemu bankowego, pozytywnej oceny zmiany klimatu inwestycyjnego, poprawiającego się stanu zaawansowania reform o charakterze rynkowym i rosnącego przekonania o ich nieodwracalności. 


\begin{tabular}{|c|c|c|c|c|c|c|c|}
\hline$\stackrel{\vec{\partial}}{\vec{\nu}}$ & $\exists$ & $\overrightarrow{6}$ & $\hat{\vec{n}}$ & $\begin{array}{l}\hat{\alpha} \\
\hat{\hat{\sigma}}\end{array}$ & \begin{tabular}{l}
$\infty$ \\
\multirow{+}{+}{} \\
$\stackrel{+}{1}$
\end{tabular} & \begin{tabular}{l}
\multirow{2}{0}{} \\
\multirow{4}{*}{}
\end{tabular} & 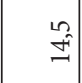 \\
\hline$\stackrel{\infty}{\stackrel{\sim}{\sim}}$ & $\stackrel{8}{\circ}$ & $\sqrt{6}$ & 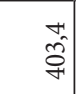 & 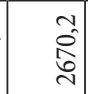 & 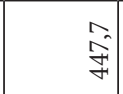 & $\stackrel{m}{\stackrel{2}{*}}$ & $\overrightarrow{\hat{n}}$ \\
\hline$\widehat{\vec{\sim}}$ & $\stackrel{+}{\Delta}$ & $\hat{\sigma}$ & 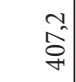 & 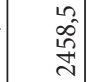 & $\begin{array}{l}0 \\
\hat{1} \\
\text { f }\end{array}$ & 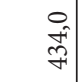 & $\begin{array}{l}0 \\
\sigma_{0}^{\prime}\end{array}$ \\
\hline $\begin{array}{l}\text { 유 } \\
\stackrel{\sim}{*}\end{array}$ & $\partial$ & $\mathscr{b}$ & $\begin{array}{l}10 \\
0 \\
o \\
o\end{array}$ & 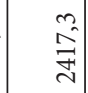 & $\begin{array}{l}+ \\
m \\
\stackrel{f}{f}\end{array}$ & $\begin{array}{l}\hat{\sigma} \\
\hat{f}\end{array}$ & જે \\
\hline$\stackrel{n}{\stackrel{n}{\vec{i}}}$ & $\stackrel{\stackrel{\sim}{\mathbb{N}}}{\mathrm{N}}$ & $\stackrel{2 n}{N}$ & 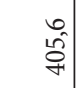 & $\begin{array}{l}\hat{0} \\
\hat{0} \\
0\end{array}$ & $\begin{array}{l}n \\
0 \\
\text { b } \\
+\end{array}$ & 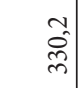 & $\vec{\approx}$ \\
\hline$\underset{\vec{D}}{\vec{\sim}}$ & $\vec{\sim}$ & $\stackrel{\circ}{\imath}$ & $\begin{array}{l}\infty \\
\stackrel{8}{+}\end{array}$ & $\begin{array}{l}0 \\
01 \\
\tilde{n} \\
n\end{array}$ & $\underset{⿱}{\stackrel{q}{q}}$ & 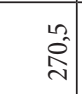 & 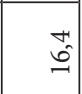 \\
\hline$\stackrel{m}{\stackrel{\sim}{\sim}}$ & 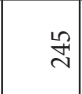 & $\cong$ & $\begin{array}{l}\overrightarrow{6} \\
\hat{0}\end{array}$ & $\begin{array}{c}0 \\
\hat{0} \\
\stackrel{+}{+}\end{array}$ & 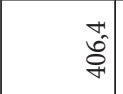 & 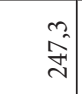 & $\overrightarrow{0}$ \\
\hline 록 & તి & $\curvearrowright$ & 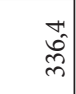 & $\begin{array}{l}m \\
\stackrel{+}{\Xi} \\
\simeq\end{array}$ & $\stackrel{+}{\stackrel{m}{m}}$ & $\stackrel{\stackrel{H}{d}}{\underset{\sim}{*}}$ & 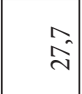 \\
\hline$\overline{\vec{\sim}}$ & 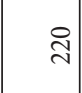 & 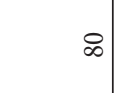 & $\stackrel{m}{m}$ & 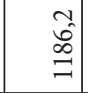 & $\begin{array}{l}\hat{\sigma} \\
\hat{\sigma}\end{array}$ & 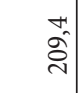 & $\overrightarrow{0}$ \\
\hline$\stackrel{\circ}{\stackrel{\sim}{\circ}}$ & తి & $\infty$ & 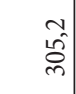 & $\begin{array}{l}\underset{f}{\mathbb{Z}} \\
\underset{I}{J}\end{array}$ & $\begin{array}{l}\infty \\
\infty \\
m \\
m\end{array}$ & $\begin{array}{l}\hat{\sigma} \\
\hat{v}\end{array}$ & 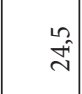 \\
\hline ஓे & $\overrightarrow{\widetilde{N}}$ & $\stackrel{\circ}{\curvearrowleft}$ & $\stackrel{0}{\stackrel{0}{n}}$ & $\begin{array}{c}\underset{\sim}{\rightarrow} \\
\underset{\infty}{\infty}\end{array}$ & $\begin{array}{l}\hat{0} \\
\stackrel{0}{\Delta}\end{array}$ & $\begin{array}{l}0 \\
6 \\
0 \\
n\end{array}$ & $\begin{array}{l}10 \\
0 \\
\sim 0 \\
\sim\end{array}$ \\
\hline 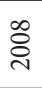 & હે & 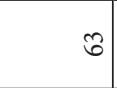 & $\begin{array}{l}\stackrel{1}{2} \\
\hat{0} \\
0 \\
-1\end{array}$ & $\hat{\vec{n}}$ & $\hat{\tilde{\hat{N}}}$ & 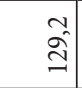 & : \\
\hline 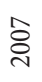 & $\stackrel{\mathscr{n}}{\underline{n}}$ & กิ & $\begin{array}{l}0 \\
\text { वे }\end{array}$ & $\begin{array}{l}n= \\
0 \\
0 \\
0 \\
n\end{array}$ & $\stackrel{-}{.}$ & 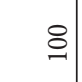 & $\stackrel{\Omega}{\Omega}$ \\
\hline 농 & $\vec{n}$ & $m$ & $\begin{array}{l}\stackrel{2}{2} \\
\stackrel{\sim}{\sim}\end{array}$ & $\begin{array}{l}\stackrel{n}{2} \\
\hat{8} \\
m \\
m\end{array}$ & $\stackrel{8}{0}$ & $\stackrel{1}{ }$ & ชิ \\
\hline 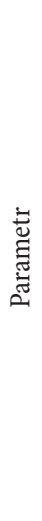 & 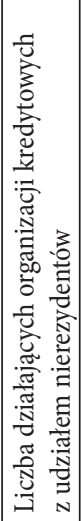 & 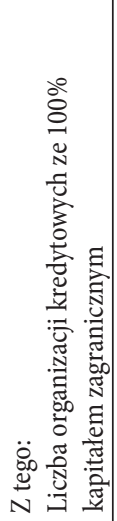 & 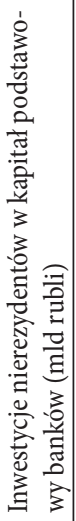 & 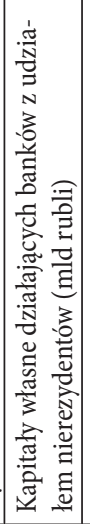 & 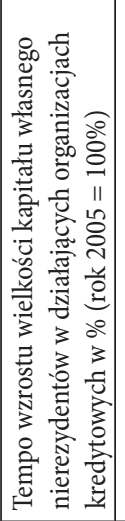 & 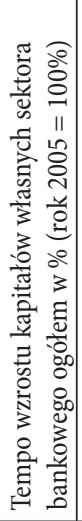 & 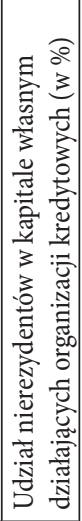 \\
\hline
\end{tabular}


Informacje o kapitałach własnych 25 banków z największym udziałem kapitału zagranicznego w 2019 r. zawarto w poniższej tabeli. Liderem w tym rankingu, bankiem o najwyższym kapitale własnym, jest bank włoski, funkcjonujący w Rosji pod nazwą UniCredit Bank. W dalszej kolejności jest to austriacki Raiffeisen Bank, a następnie amerykański JPMorgan International.

Tabela 4. Kapitały własne największych banków ze 100\% udziałem kapitału zagranicznego w Rosji na dzień 1 stycznia 2019 r.

\begin{tabular}{|l|l|l|l|l|l|}
\hline & \multicolumn{1}{|c|}{ Nazwa banku } & Numer & Siedziba & \multicolumn{1}{|c|}{$\begin{array}{c}\text { Kwota } \\
\text { kapitału } \\
\text { założyciel- } \\
\text { skiego } \\
\text { (mln rubli) }\end{array}$} & $\begin{array}{c}\text { Kraj } \\
\text { pochodzenia } \\
\text { kapitału }\end{array}$ \\
\hline 1. & UniCredit Bank S.A. & 1 & Moskwa & 40438,3 & Włochy - 100\% \\
\hline 2. & Raiffeisen Bank S.A. & 3292 & Moskwa & 36711,3 & Austria - 100\% \\
\hline 3. & JPMorgan International & 2629 & Moskwa & 15915,3 & USA - 100\% \\
\hline 4. & MUFG Ewrazja Bank S.A. & 3465 & Moskwa & 10917,9 & Japonia - 100\% \\
\hline 5. & Bank Intesa & 2216 & Moskwa & 10820,2 & $\begin{array}{l}\text { Luksemburg- 53\%, } \\
\text { Włochy - 47\% }\end{array}$ \\
\hline 6. & ASBS Bank & 3475 & Moskwa & 10809,5 & Chiny - 100\% \\
\hline 7. & Mizuho Bank (Moskwa) & 3337 & Moskwa & 8783,3 & Japonia - 100\% \\
\hline 8. & Credit Europe Bank & 3311 & Moskwa & 8334,9 & $\begin{array}{l}\text { Turcja - 90\% } \\
\text { Holandia - 10\% }\end{array}$ \\
\hline 9. & Czajna Sielskochozjastwiennyj Bank & 3529 & Moskwa & 7556,0 & Chiny - 100\% \\
\hline 10. & HSBC Sp. z o.o. & 3290 & Moskwa & 6888,0 & Holandia - 100\% \\
\hline 11. & Tinkoff Bank S.A. & 2673 & Moskwa & 6772,0 & Cypr - 100\% \\
\hline 12. & Sumitomo Mitsui Rus Bank S.A. & 3494 & Moskwa & 6400,0 & Japonia - 100\% \\
\hline 13. & J\&T Bank S.A. & 3061 & Moskwa & 6355,0 & Czechy - 100\% \\
\hline 14. & RN Bank S.A. & 170 & Moskwa & 6069,0 & Holandia - 100\% \\
\hline 15. & BNP PARIBAS Bank S.A. & 3407 & Moskwa & 5798,2 & Francja - 100\% \\
\hline 16. & Toyota Bank S.A. & 3470 & Moskwa & 5440,0 & Japonia - 100\% \\
\hline 17. & Moskommercbank S.A. & 3365 & Moskwa & 4923,5 & $\begin{array}{l}\text { Kazachstan - } \\
100 \%\end{array}$ \\
\hline 18. & İshbank S.A. & 2867 & Moskwa & 4763,0 & Turcja - 100\% \\
\hline 19. & China Construction Bank Sp. z o.o. & 3515 & Moskwa & 4200,0 & Chiny - 100\% \\
\hline 20. & $\begin{array}{l}\text { Home Credit and Finance Bank } \\
\text { Sp. z o.o. }\end{array}$ & 316 & Moskwa & 4173,0 & $\begin{array}{l}\text { Holandia - } \\
99,992 \% \\
\text { Czechy - 0,008\% }\end{array}$ \\
\hline 21. & Bank MBA - Moskwa Sp. z o.o. & 3395 & Moskwa & 4091,8 & $\begin{array}{l}\text { Azerbejdżan - } \\
100 \%\end{array}$ \\
\hline 22. & UBS Bank Sp. z o.o. & 3463 & Moskwa & 3450,0 & Szwajcaria - 100\% \\
\hline 23. & Bank of China S.A. & 2309 & Moskwa & 3435,0 & Chiny - 100\% \\
\hline
\end{tabular}

5 Kurs walutowy dolara USA do rosyjskiego rubla 1 stycznia 2019 r. wynosił 65,33 rubla za 1 dolara USA. 


\begin{tabular}{|l|l|l|l|l|l|}
\hline 24. & Danske Bank S.A. & 3307 & $\begin{array}{l}\text { Sankt Pe- } \\
\text { tersburg }\end{array}$ & 2748,0 & Dania - 100\% \\
\hline 25. & SEB Bank S.A. & 3235 & $\begin{array}{l}\text { Sankt Pe- } \\
\text { tersburg }\end{array}$ & 2329,0 & Szwecja - 100\% \\
\hline
\end{tabular}

Źródło: Bank Rosji, 2019a.

Większość banków z udziałem kapitału zagranicznego charakteryzuje się stosunkowo niewielkimi kapitałami własnymi. Świadczą o tym pozycje banków zagranicznych w rankingu banków rosyjskich zestawionym według wielkości kapitałów własnych. Spośród 50 największych banków działających w Rosji w 2019 r. te z kapitałem zagranicznym stanowiły niewielką grupę 11 banków. Kapitał własny największego banku z kapitałem zagranicznym włoskiego UniCredit Bank S.A. plasuje go na 9 miejscu w rankingu banków działających w Rosji i stanowi zaledwie 4,3\% największego banku rosyjskiego kapitału Sbierbanku FR, 9,6\% kapitału drugiego w rankingu Wniesztorgbanku i ponad 20\% kapitału własnego Gazprombanku (3 pozycja w rankingu banków rosyjskich).

Magazyn „Forbes” przeanalizował ratingi i wyniki finansowe rosyjskich banków i na tej podstawie uszeregował 100 banków według poziomu wiarygodności.

Spośród banków poddanych analizie przez rosyjskie agencje ratingowe zdecydowana większość uzyskała wysoką ocenę AAA. Zagraniczne agencje ratingowe zgodnie ze standardami sporządzania ratingów - nie przyznawały rosyjskim bankom oceny wyższej niż rating kraju (między $\mathrm{BBB}-\mathrm{i} \mathrm{BB}+$ ). Za najbardziej wiarygodne banki, czyli o ratingach $\mathrm{BBB}-\mathrm{i} \mathrm{BB}+$, uważa się największe banki rosyjskie ( $w$ większości z kapitałem państwowym) i banki z udziałem kapitału zagranicznego. W tabeli 6 zawarto listę 25 banków poddanych ocenie przez co najmniej jedną agencję ratingową. Najwyższe oceny zdobył włoski UniCredit Bank, który poddał się analizie agencjom Standard \& Poor's (BBB-), Fitch (BBB-) i rosyjskim - Ekspert RA (ruAAA) i AKRA (AAA). 


\begin{tabular}{|c|c|c|c|c|c|c|c|c|c|c|c|c|c|c|}
\hline 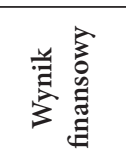 & $\frac{\sim}{\vec{\infty}}$ & $\begin{array}{l}\infty \\
\infty \\
\stackrel{0}{=}\end{array}$ & ڤू & $\hat{\sigma}$ & $\stackrel{\infty}{=}$ & $\hat{m}$ & D & הీ & $\stackrel{\infty}{\stackrel{n}{n}^{\prime}}$ & $\stackrel{\infty}{-}$ & $\approx$ & $\stackrel{m}{\rightarrow}$ & $\stackrel{\infty}{\rightarrow}$ & $\overrightarrow{0}$ \\
\hline 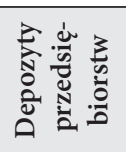 & $\begin{array}{l}2 \\
\hat{a} \\
\infty \\
\stackrel{\sim}{2}\end{array}$ & $\begin{array}{l}0 \\
\infty \\
2 \\
\text { in }\end{array}$ & 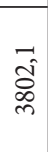 & 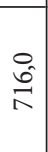 & $\stackrel{0}{\stackrel{0}{\sharp}}$ & $\begin{array}{c}\hat{\sigma} \\
\hat{f}\end{array}$ & $\ddot{0}$ & 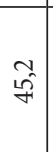 & $\stackrel{+}{=}$ & $\hat{o}$ & $\stackrel{n}{\mathbb{N}}$ & $\begin{array}{l}10 \\
\Omega\end{array}$ & $\hat{\stackrel{n}{0}}$ & $\begin{array}{l}\infty \\
\text { in }\end{array}$ \\
\hline 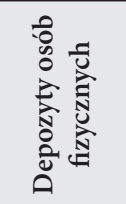 & $\begin{array}{l}\overrightarrow{\hat{q}} \\
\text { के } \\
\stackrel{2}{2}\end{array}$ & 告 & $\begin{array}{l}\hat{\sigma} \\
\hat{\sigma}\end{array}$ & $\begin{array}{l}0 \\
\stackrel{\Omega}{\Omega}\end{array}$ & $\begin{array}{l}\stackrel{0}{\circ} \\
\stackrel{\sim}{\sim}\end{array}$ & 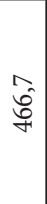 & $\overrightarrow{0}$ & $\begin{array}{l}\stackrel{\hat{\sigma}}{\hat{\sim}} \\
\hat{n}\end{array}$ & $\begin{array}{l}\hat{0} \\
\stackrel{\sim}{\sim}\end{array}$ & $\stackrel{\infty}{0}$ & $\stackrel{+}{\sim}$ & $\hat{n}$ & $\vec{m}$ & $\vec{m}$ \\
\hline 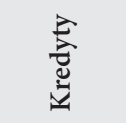 & $\begin{array}{l}0 \\
10 \\
\infty \\
2 \\
2\end{array}$ & $\begin{array}{l}2 \\
2 \\
2 \\
0 \\
0\end{array}$ & ज̂ & $\begin{array}{l}\tilde{\infty} \\
\hat{\varnothing}\end{array}$ & $\underset{\mathbb{N}}{\stackrel{\circ}{N}}$ & $\begin{array}{l}+ \\
\hat{\delta}\end{array}$ & $\overrightarrow{0}$ & $\begin{array}{l}\overrightarrow{\hat{N}} \\
\vec{N}\end{array}$ & $\begin{array}{l}\stackrel{H}{\sim} \\
\stackrel{\leftrightarrow}{\sim}\end{array}$ & $\stackrel{+}{\stackrel{+}{N}}$ & $\hat{\sigma}$ & $\stackrel{\stackrel{े}{\Xi}}{\underline{\Xi}}$ & ชิ & $\stackrel{\infty}{\stackrel{\Xi}{J}}$ \\
\hline 吾 & $\begin{array}{l}\infty \\
1 n \\
n \\
\infty \\
n\end{array}$ & $\begin{array}{l}0 \\
\tilde{n} \\
\end{array}$ & $\begin{array}{l}\hat{0} \\
\vec{\sigma}\end{array}$ & $\begin{array}{l}\infty \\
\stackrel{\alpha}{\Omega}\end{array}$ & $\begin{array}{l}\infty \\
\hat{n} \\
\end{array}$ & 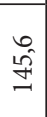 & $\vec{D}$ & $\begin{array}{l}0 \\
\hat{\sigma}\end{array}$ & $\overrightarrow{\sigma^{\prime}}$ & $\begin{array}{l}\infty \\
\infty \\
\stackrel{0}{\sim}\end{array}$ & $\begin{array}{l}0 \\
\hat{m}^{0}\end{array}$ & $\hat{\vec{N}}$ & $\stackrel{\infty}{\stackrel{\infty}{n}^{n}}$ & $\tilde{\vartheta}^{m}$ \\
\hline 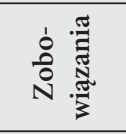 & $\begin{array}{l}\stackrel{-}{=} \\
\stackrel{-}{N}\end{array}$ & $\begin{array}{l}0 \\
\stackrel{0}{n} \\
\tilde{n}\end{array}$ & $\frac{m}{\stackrel{2}{n}}$ & $\begin{array}{l}\hat{\sigma} \\
\stackrel{0}{=}\end{array}$ & $\hat{\sigma}$ & $\begin{array}{l}\dot{H} \\
\stackrel{0}{0} \\
\Omega\end{array}$ & $\overrightarrow{0}$ & $\begin{array}{l}\stackrel{2}{\AA} \\
\stackrel{\sim}{n}\end{array}$ & స్ & $\begin{array}{l}\overrightarrow{\widehat{D}} \\
\hat{\sigma}\end{array}$ & 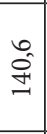 & $\stackrel{\stackrel{M}{0}}{\stackrel{0}{A}^{\prime}}$ & $\begin{array}{l}\stackrel{n}{\hat{S}} \\
\hat{\Xi}\end{array}$ & $\stackrel{\circ}{\stackrel{0}{0}}$ \\
\hline$\frac{\pi}{4}$ & $\begin{array}{l}n \\
\hat{a} \\
\vec{m}\end{array}$ & 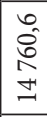 & $\begin{array}{l}\overrightarrow{\tilde{N}} \\
\hat{\sigma}\end{array}$ & $\begin{array}{l}0 \\
\hat{~} \\
\text { ల్ }\end{array}$ & $\begin{array}{l}\stackrel{\text { ñ }}{N} \\
\stackrel{\Omega}{=}\end{array}$ & $\begin{array}{l}0 \\
\stackrel{0}{0} \\
\stackrel{\Xi}{=}\end{array}$ & \begin{tabular}{|c|}
$*$ \\
6 \\
$i$ \\
$\tilde{n}$ \\
10 \\
\end{tabular} & $\begin{array}{l}\hat{\sigma} \\
\hat{\Xi}\end{array}$ & $\begin{array}{l}\infty \\
\stackrel{\sim}{N} \\
\text {. }\end{array}$ & $\begin{array}{l}\text { } \\
\text { }\end{array}$ & $\stackrel{\overbrace{}}{\stackrel{1}{I}}$ & Ô & $\begin{array}{l}\tilde{1} \\
\stackrel{0}{J} \\
=\end{array}$ & 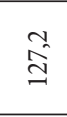 \\
\hline 莫 & 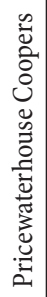 & 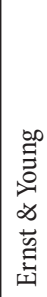 & 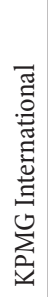 & 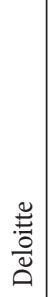 & 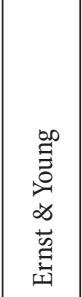 & 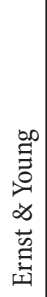 & 氖 & 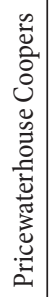 & 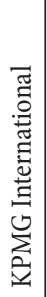 & 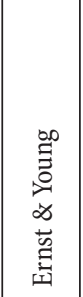 & 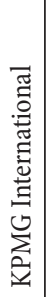 & 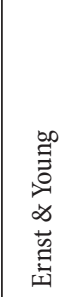 & 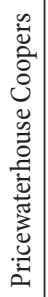 & 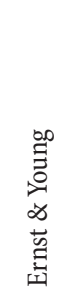 \\
\hline 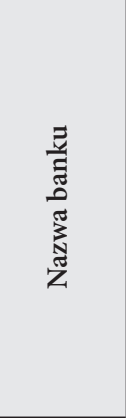 & 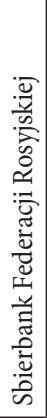 & 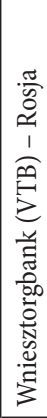 & $\begin{array}{l}\text { בै } \\
\text { है } \\
\text { : } \\
\text { : }\end{array}$ & 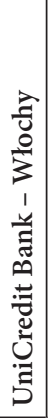 & 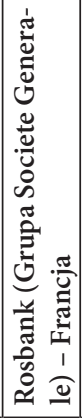 & 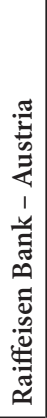 & 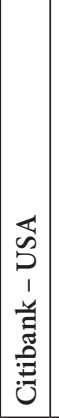 & 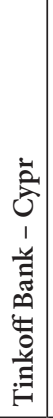 & 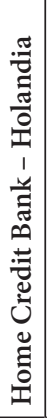 & 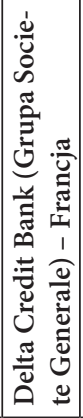 & 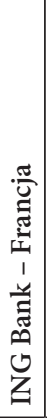 & 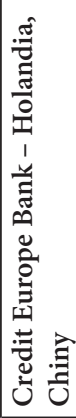 & 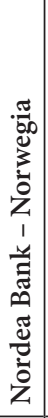 & 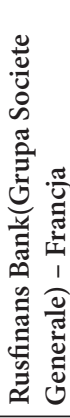 \\
\hline 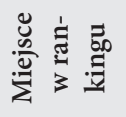 & - & $\sim$ & $m$ & $a$ & $=$ & $\simeq$ & 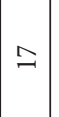 & $\vec{\sim}$ & $\ddot{\sim}$ & r & $\hat{m}$ & F & 字 & $\stackrel{\infty}{+}$ \\
\hline
\end{tabular}

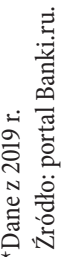


Tabela 6. Ranking 25 najbardziej wiarygodnych banków rosyjskich (stan na dzień 1 stycznia 2019 r.)

\begin{tabular}{|c|c|c|c|c|c|}
\hline $\mathrm{Nr}$ & Nazwa & 莺 & 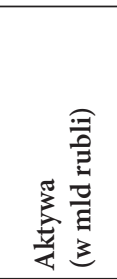 & 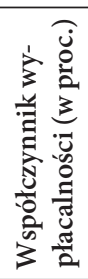 & 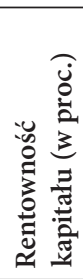 \\
\hline 1 & UniCredit Bank & $\begin{array}{l}\text { ruAAA (Ekspert RA), } \\
\text { BBB- (Standard \& Poor's) } \\
\text { BBB- (Fitch) } \\
\text { AAA (AKRA) }\end{array}$ & 1395,8 & 16,15 & 9,7 \\
\hline 2 & Raiffeisen Bank & $\begin{array}{l}\text { ruAAA (Ekspert RA) } \\
\text { Baa3 (Moody’s) } \\
\text { BBB- (Fitch) } \\
\text { AAA (AKRA) }\end{array}$ & 1141,6 & 13,03 & 18,9 \\
\hline 3 & $\begin{array}{l}\text { Rosbank (Grupa Société } \\
\text { Générale) }\end{array}$ & $\begin{array}{l}\text { ruAAA (Ekspert RA) } \\
\text { Ba1 (Moody's) } \\
\text { BBB- (Fitch) } \\
\text { AAA (AKRA) }\end{array}$ & 1110,2 & 13,09 & 9,0 \\
\hline 4 & Sbierbank Federacji Rosyjskiej & $\begin{array}{l}\text { Baa3 (Moody’s) } \\
\text { BBB- (Fitch) } \\
\text { AAA (AKRA) }\end{array}$ & 27662,0 & 14,89 & 20,4 \\
\hline 5 & Wniesztorgbank (VTB) & $\begin{array}{l}\text { ruAAA (Ekspert RA) } \\
\text { Baa3 (Moody's) } \\
\text { BBB- (Standard \& Poor's) }\end{array}$ & 13981,2 & 11,34 & 19,4 \\
\hline 6 & Citibank & $\begin{array}{l}\text { BBB- (Fitch) } \\
\text { AAA (AKRA) }\end{array}$ & 552,6 & 14,5 & 22,1 \\
\hline 7 & ING Bank (Ewrazja) & $\begin{array}{l}\text { BBB- (Fitch) } \\
\text { AAA (AKRA) }\end{array}$ & 171,8 & 35,16 & 5,0 \\
\hline 8 & Nordea Bank & $\begin{array}{l}\text { BBB- (Fitch) } \\
\text { AAA (AKRA) }\end{array}$ & 128,2 & 40,22 & 6,2 \\
\hline 9 & HSBC & $\begin{array}{l}\text { BBB- (Fitch) } \\
\text { AAA (Akra) }\end{array}$ & 83,4 & 23,06 & 11,8 \\
\hline 10 & Crédit Agricole & $\begin{array}{l}\text { BBB- (Fitch) } \\
\text { AAA (AKRA) }\end{array}$ & 58,3 & 40,55 & 0,3 \\
\hline 11 & $\begin{array}{l}\text { Skandinaviska Enskilda Banken } \\
\mathrm{AB}\end{array}$ & $\begin{array}{l}\text { BBB- (Fitch) } \\
\text { AAA (AKRA) }\end{array}$ & 51,3 & 80,77 & 10,3 \\
\hline 12 & $\begin{array}{l}\text { Delta Credit Bank (Grupa Socié- } \\
\text { té Générale) }\end{array}$ & $\begin{array}{l}\text { Ba1 (Moody's) } \\
\text { AAA (AKRA) }\end{array}$ & 200,5 & 12,57 & 10,5 \\
\hline 13 & $\begin{array}{l}\text { Rusfinans Bank (Grupa Société } \\
\text { Générale) }\end{array}$ & $\begin{array}{l}\text { Bal (Moody's) } \\
\text { AAA (AKRA) }\end{array}$ & 128,0 & 11,27 & 1,7 \\
\hline 14 & Bank of China & $\begin{array}{l}\text { ruAA (Ekspert RA) } \\
\text { BBB- (Fitch) }\end{array}$ & 39,5 & 29,75 & 3,7 \\
\hline 15 & Bank Intesa & $\begin{array}{l}\text { ruA (Ekspert RA) } \\
\text { BBB- (Fitch) }\end{array}$ & 62,2 & 17,55 & 2,8 \\
\hline
\end{tabular}


46 | Przegląd Prawno-Ekonomiczny

\begin{tabular}{|l|l|l|c|c|c|}
\hline 16 & Deutsche Bank & AAA (AKRA) & 85,0 & 26,1 & 6,3 \\
\hline 17 & Mizuho Bank (Moskwa) & AAA (AKRA) & 84,5 & 59,45 & 5,8 \\
\hline 18 & Toyota Bank & AAA (AKRA) & 69,4 & 16,88 & 12,2 \\
\hline 19 & MUFG Bank (Ewrazja) & AAA (AKRA) & 68,0 & 99,82 & 7,7 \\
\hline 20 & Comercbank (Ewrazja) & AAA (AKRA) & 64,3 & 24,69 & 13,8 \\
\hline 21 & BNP Paribas & AAA (AKRA) & 49,0 & 67,95 & 2,3 \\
\hline 22 & Volkswagen Bank RU & AAA (AKRA) & 43,9 & 38,13 & 6,1 \\
\hline 23 & JPMorgan Bank International & AAA (AKRA) & 35,8 & 58,41 & 5,4 \\
\hline 24 & Gazprombank & $\begin{array}{l}\text { ruAA+ (Ekspert RA) } \\
\text { Bal (Moody's) } \\
\text { BB+ (Standard \& Poor's) } \\
\text { BB+ (Fitch) } \\
\text { AA (AKRA) }\end{array}$ & 6265,2 & 11,2 & 3,1 \\
\hline 25 & Alfa Bank & $\begin{array}{l}\text { ruAA (Ekspert RA) } \\
\text { Bal (Moody's) } \\
\text { BB+ (Standard \& Poor's) } \\
\text { BB+ (Fitch) } \\
\text { AA (AKRA) }\end{array}$ & 3355,3 & 13,52 & 28,2 \\
& $\begin{array}{l} \\
\end{array}$ & & \\
\hline
\end{tabular}

Źródło: Verzbitsky, 2019.

Ważną cezurą czasową dla obecności kapitału zagranicznego w rosyjskiej bankowości był rok 2014. Od tego roku odnotowuje się spadek liczby banków z udziałem kapitału zagranicznego w bankowości rosyjskiej, głównie za sprawą dwóch grup czynników: ekonomicznych i politycznych. Czynniki ekonomiczne to rosnąca konkurencja ze strony coraz silniejszych banków rosyjskich, obniżająca się atrakcyjność inwestowania w Rosji przy utrzymującym się wysokim ryzyku i niepewności inwestowania na rynku rosyjskim oraz wprowadzone w $2014 \mathrm{r}$. sankcje gospodarcze Zachodu wobec Rosji z racji konfliktu rosyjsko-ukraińskiego. Czynniki polityczne to brak jasnej deklaracji Rosji odnośnie do wycofania się z konfliktu rosyjsko-ukraińskiego, akceptacja dla reżimu Łukaszenki na Białorusi, podejrzenia wobec rosyjskich służb specjalnych o ich udział w zamachach na życie przeciwników politycznych (A. Nawalnyj) czy byłych pracowników rosyjskiego wywiadu (S. Skripal).

Czynnikiem, który wyraźnie osłabił zainteresowanie nowych inwestorów zagranicznych rynkiem rosyjskim, także bankowością, były sankcje gospodarcze zastosowane wobec Rosji przez kraje Zachodu. Zostały one wprowadzone, gdy potwierdzono rosyjskie wsparcie dla ujawnionych na Ukrainie w okresie 2013-2014 tendencji separatystycznych. Rosja włączyła się wówczas w działania wojenne zmierzające do odłączenia od Ukrainy Krymu i dwóch jej republik ługańskiej i donieckiej. Rosja w tym okresie była postrzegana jako kraj nie tylko wspierający wojnę na Ukrainie, ale i przeciwdziałający działaniom propokojowym podejmowanym przez rządy krajów Unii Europejskiej (Kiedy, 2017). Kiedy nie 
udało się zażegnać konfliktu na Ukrainie, najpierw Unia Europejska, a potem inne kraje świata zastosowały wobec Rosji różnorodne sankcje (Żukowska, 2018). Sankcjami zostały objęte osoby fizyczne i prawne, których działania zagrażały suwerenności i integralności terytorialnej Ukrainy, zwykle pochodzące z Rosji, ale też z Krymu i ukraińskich regionów: donieckiego i ługańskiego. Lista osób fizycznych objętych sankcjami UE od 2014 r. ulega modyfikacjom inp. w grudniu 2017 r. obejmowała 160 osób, a liczba instytucji i organizacji to 40 podmiotów (Council of the European Union, 2017). W marcu 2018 r. liczba osób objętych sankcjami zmniejszyła się do 150, a liczba innych podmiotów do 38 .

Sankcjami w grupie osób fizycznych objęto (Wsie sankcji, 2017):

- rosyjskich polityków i urzędników państwowych oraz biznesmenów;

- obywateli rosyjskich aktywnie popierających rosyjską agresję na Ukrainie;

- mieszkańców Krymu i obywateli innych krajów popierających rosyjską agresję na Ukrainie;

- działaczy politycznych reprezentujących republikę doniecką i ługańską popierających rosyjską agresję na Ukrainie;

- byłego prezydenta Ukrainy Wiktora Janukowycza, członków jego rodziny i osoby z jego bliskiego otoczenia;

- rosyjskie organizacje społeczne popierające rosyjską agresję na Ukrainie;

- różne instytucje państwowe i organizacje społeczne republik donieckiej oraz ługańskiej, w tym władze tych republik, kilkanaście zbrojnych oddziałów wojskowych, związki przedsiębiorstw, stowarzyszenia oraz ruchy polityczne i społeczne oficjalnie popierające rosyjską agresję na Ukrainie.

W grupie przedsiębiorstw (osób prawnych) objętych sankcjami USA, Kanady i UE w różnych okresach znalazło się ponad 350 rosyjskich i zagranicznych podmiotów. Każdy z krajów stosujących sankcje podejmował indywidualne decyzje wobec obejmowanych nimi podmiotów. Te wprowadzane wobec przedsiębiorstw miały różny charakter. Wśród nich da się wyróżnić dwa rodzaje sankcji: zamrożenie aktywów i sankcje sektorowe (wobec sektora paliwowego, finansowego i zbrojeniowego), polegające na ograniczeniu eksportu, reeksportu i importu oraz ograniczenie kredytowania. Nie został stworzony jeden zsynchronizowany wykaz podmiotów objętych sankcjami, chociaż niektóre osoby fizyczne czy przedsiębiorstwa znalazły się na liście podmiotów sankcjonowanych nawet przez kilka krajów.

W rezultacie zastosowanych sankcji w gospodarce rosyjskiej w pierwszym okresie odnotowano spadek tempa wzrostu gospodarczego i obniżenie PKB, zmniejszenie dochodów ze sprzedaży ropy naftowej i gazu, co skomplikowało sytuację budżetu państwa. Nastąpił wzrost inflacji oraz cen, w największym 
stopniu dóbr żywnościowych, obniżył się globalny popyt, odnotowano także podwyższenie stóp procentowych i oprocentowania kredytów oraz wzrost wielkości przeterminowanych kredytów i niewypłacalność wielu kredytobiorców. Podmioty rosyjskie doświadczyły utrudnień lub braku dostępu do kredytów zagranicznych. Wystąpił istotny spadek obrotów handlowych z zagranicą, spadek poziomu rezerw walutowych, a także doszło do silnej deprecjacji waluty krajowej. Nastąpił także wywóz zagranicznych aktywów, odnotowano odpływ kapitału zagranicznego i zmniejszenie turystyki zagranicznej. W późniejszym okresie gospodarka rosyjska antycypowała zastosowane sankcje i skutki ich oddziaływania stały się mniej istotne dla tempa wzrostu gospodarczego. Jednakże napływ kapitału zagranicznego osłabiony na skutek sankcji gospodarczych nie został odbudowany. W ostatnim okresie (2018-2020) także obserwuje się silny odpływ walut zagranicznych z Rosji. Jest to zarówno wywóz kapitału zagranicznego, jak i prywatnego kapitału rosyjskiego. Część odpływającego kapitału dotyczy spłaty kredytów zaciągniętych zagranicą, wycofywania kapitału zagranicznego z rynku rządowych papierów wartościowych finansujących zadłużenie wewnętrzne Rosji. Inwestorzy zagraniczni nadal obawiają się rozszerzenia sankcji gospodarczych wobec Rosji. Dodatkowo wiele sektorów gospodarki rosyjskiej na skutek zastosowanych restrykcji w 2014 r. nie ma możliwości kredytowania się zagranicą, co osłabia napływ kapitału do Rosji (Ottok kapitała, 2020). W połowie $2020 \mathrm{r}$. sankcje gospodarcze UE i innych krajów wobec Rosji zostały przedłużone do końca roku 2020.

\section{Zakończenie}

Podsumowując ewolucję obecności kapitału zagranicznego w systemie bankowym Rosji, należy stwierdzić, że wpływ na ten proces miały czynniki zarówno ekonomiczne, jak i polityczne. Czynniki ekonomiczne to: oczekiwania wysokiej dochodowości z inwestycji w rosyjskiej bankowości, wysoki poziom ryzyka inwestycji, potrzeba rozszerzenia działalności na rosyjski rynek przez światowe instytucje finansowe. Czynniki polityczne to ostrożna polityka licencyjna banku centralnego (Banku Rosji) zmierzająca do ochrony rodzimego rynku bankowego, surowa weryfikacja kapitału zagranicznego napływającego do bankowości, wysokie wymagania kapitałowe, sankcje gospodarcze wobec Rosji w konsekwencji militarnej interwencji na Ukrainie, protekcyjna polityka wobec rodzimych banków. Biorąc pod uwagę skutki oddziaływania tych czynników 
na obecność kapitału zagranicznego w rosyjskim systemie bankowym, można wyróżnić następujące etapy:

- Okres początkowy transformacji - lata 1990-1998 -kiedy występowała silna presja kapitału zagranicznego na rosyjski rynek bankowy. Była ona ograniczana przez władze rosyjskie poprzez surową politykę licencyjną i wymagania kapitałowe oraz organizacyjne stawiane kapitałowi zagranicznemu. Spodziewano się w tym okresie napływu kapitału spekulacyjnego liczącego na szybkie zyski w transformującej się gospodarce.

- Lata 1999-2013 to okres ciągłego wzrostu obecności kapitału zagranicznego w rosyjskim systemie bankowym. Wzrastają wszystkie parametry cechujące tę obecność - liczba działających banków z kapitałem zagranicznym, wielkość zainwestowanego kapitału, wzrost z roku na rok wartości zaangażowanego kapitału zagranicznego w rosyjskich bankach oraz zwiększenie udziału kapitału zagranicznego w kapitale własnym banków ogółem.

- Lata 2014-2020 to czas, kiedy obserwuje się zahamowanie procesu tworzenia nowych banków i zmniejszenie liczby już działających. Można to powiązać z sankcjami nałożonymi na obywateli i przedsiębiorstwa rosyjskie, które sprzyjały rosyjskiej agresji na Ukrainie w 2014 r. Wydaje się także, że wprowadzone sankcje zahamowały „powrót” do Rosji kapitału wywiezionego we wcześniejszym okresie. W tym czasie dokonują się także silne procesy koncentracji zachodzące w bankowości nie tylko w Rosji, lecz także na świecie. Proces koncentracji ilościowej i jakościowej w bankach z udziałem kapitału zagranicznego w Rosji wiąże się $\mathrm{z}$ umacnianiem pozycji tych instytucji finansowych na rosyjskim rynku usług bankowych. Banki z kapitałem zagranicznym są obecnie znaczącym elementem sektora bankowego w Rosji. O ich sile i pozycji świadczy ocena ich wiarygodności przez prestiżowy magazyn „FORBES”, gdzie na 25 najbardziej wiarygodnych banków działających w Rosji, aż 21 to banki z udziałem kapitału zagranicznego.

Epidemia koronawirusa, która ogarnęła cały świat w 2020 r., dołączy zapewne do grupy niekorzystnych czynników wpływających na obecność kapitału zagranicznego w rosyjskiej bankowości. Na skutek epidemii, ograniczenia kontaktów i wyjazdów zagranicznych, zwiększenia niepewności oraz ryzyka inwestycji należy oczekiwać zmniejszenia napływu kapitału zagranicznego do rosyjskiej bankowości. 


\section{Bibliografia}

Bank Rosji. (2000). Informacija o kreditnych organizacijach s innostronnymi investicyjami na 1 janwarija 2000 goda. a) Priłożenije 7. b) Priłożenije 6. Moskva.

Bank Rosji. (2003). Otczot o razwitii bankowskogo sektora i bankowskogo nadzora w 2002 godu, Moskva. Pobrano z http: www.cbr.ru (30.10.2003).

Bank Rosji. (2004). Obzor finansowogo rynka, Moskva, s. 3, tab. 1.1.2.

Bank Rosji. (2005). Otcziot o razwitii bankowskogo siektora i bankowskogo nadzora w 2004 godu. Moskva.

Bank Rosji. (2005-2019). Obzor bankowskogo siektora Rossijskoj Fiedieraciji, Moskva, fiewral 2005, fiewral 2007, janwar 2010, tab. 90; oraz awgust 2011, awgust 2014, nojabr 2015, awgust 2017, awgust 2019, tab. 10.

Bank Rosji. (2006). Informacija o kreditnych organizacijach s uczastijem nierezidentow na 1 janwaria 2006 goda. Moskva.

Bank Rosji. (2008). Obzor bankowskogo siektora Rossijskoj Fiedieraciji. Moskva, fievral 2008, nr 46, tab. 9.

Bank Rosji. (2019a). Informacija o diejstwujuszczich kreditnych organizacjach suczastiem nierezidentov na 1 apriela 2019 goda. Pobrano z https://www.cbr.ru/Collection/ Collection/File/15760/PUB_190101.pdf (08.09.2019).

Bank Rosji. (2019b). Otcziot o razwitii bankowskogo sektora i bankowskogo nadzora w 2018 godu. Pobrano z www.cbr.ru/statistics/bank_system/print.asp?file=inform_07. htm (14.07.2019).

Bank Rosji. (2020). Informacija o diejstwujuszczich kreditnych organizacjach s uczastiem nierezidentov na 1 apriela 2020 goda. Pobrano z http://old.cbr.ru/Collection/ Collection/File/27599/PUB_200101.pdf (01.10.2020).

Bartosik, L. (2010). Kapitał zagraniczny w systemie bankowym Federacji Rosyjskiej. Zeszyty Naukowe Wyższej Szkoły Bankowej we Wrocławiu, 16, 53-82.

Bażan, A. I., Masliennikow, A. A. (2000). Sostojanije rossijskoj bankowskoj sistiemy i probliemy jejo restrukturizowanija (s. 61-62). Moskva.

Biuletien Bankovskoj Statystiki. (1998-2020). Moskva: Jeżemiesiacznik. Czast 4. Otdielnyje pokazatieli diejatielnosti finansovych organizacij, tab. 4.1.3., 4.1.4.

Council of the European Union. (b.d.). List of persons and entities under EU restrictive measures over the territorial integrity of Ukraine. Pobrano $\mathrm{z}$ http://www.consilium.europa.eu/media/21891/20170914-list-of-designated-persons-and-entities. pdf (13.12.2017).

Informacija o diejstwujuszczich kreditnych organizacjach c uczastiem nierezidentow. (b.d.). Pobrano z https://www.cbr.ru/analytics/bank_system/PUB_120701/ (10.02.2020).

Iwanicz-Drozdowska, M., Bongini, P., Smaga, P., Witkowski, B. (2017). Rola kapitału zagranicznego w sektorze bankowym dla stabilności finansowej i rozwoju go- 
spodarczego krajów postkomunistycznych. Annales Universitatis Mariae Curie-Skłodowska, 51(5), 129-137.

Kiedy i jak UE przyjmuje sankcje? (b.d.). Pobrano z http://www.consilium.europa.eu/pl/ policies/sanctions/ukraine-crisis/ (08.07.2017).

Lepietikov, D. W. (2004). Bankovskaja integracija Rossii w Jevropu: pogłoszczenije ili partniorstvo? (s. 17). Pobrano z http://www.dcenter.ru/acr_view.cgi?id=576.

Ottok kapitała iż Rossii uskoriłsja wtroe. (b.d.). Pobrano z https://www.finanz.ru/novosti/valyuty/ottok-kapitala-iz-rossii-uskorilsya-vtroe-1027528265 (20.09.2020).

Portal Banki.ru. Pobrano z https://www.banki.ru/banks/ratings/msfo/ (28.08.2019).

Tschoegl, A. E. (2003). Financial Crises \& the Presence of Foreign Banks, Philadelphia, 5 December 2003. Speech prepared for and presented at the World Bank conference: Systemic Financial Distress: Containment and Resolution, 7-8 October 2003.

Verzbitsky, A. (2019). 100 nadiożnych rosyjskich banków 2019. Ratings Forbes. Pobrano z https://www.forbes.ru/finansy-i-investicii/373477-100-nadezhnyh-rossiyskih-bankov-2019-reyting-forbes (16.09.2019).

Wiernikow, A. W. (2002a). Ocienka massztabov prisutswija inostarannych bankov. Diengi i Kredit, 1, 25-27.

Wiernikow, A. W. (2002b). Strategii inostrannych bankov w Rossii. Voprosy Ekonomiki, 12, 68-85.

Wsie sankcji zapada protiw Rosii. (b.d.). Pobrano $\mathrm{z}$ http://tass.ru/mezdunarodnaja-panorama/1055587/8 (08.10.2017).

Żukowska, H. (2018). Sankcje wobec Rosji a gospodarka rosyjska w okresie 2014-2018. Roczniki Ekonomii i Zarzadzania KUL, 10(46), 3, 97-132.

Żukowska, H. (2019). System bankowy w Rosji. Ewolucja do początku XXI wieku (s. 195208, 248-255). Lublin: Wydawnictwo KUL.

Żukowski, M., Żukowska, H. (2008). Rola banków z kapitałem zagranicznym w systemie bankowym Rosji. W: L. Dziawgo (red.), Wspótczesne finanse: stan i perspektywy rozwoju bankowości (s. 435-453). Toruń: Wydawnictwo Uniwersytetu Mikołaja Kopernika.

\section{Streszczenie}

Celem artykułu jest zaprezentowanie ewolucji obecności kapitału zagranicznego w systemie bankowym Rosji od początku okresu transformacji do początku lat 20. XXI w. Z przeprowadzonej analizy wynika, że w okresie 30 lat tych przemian w Rosji można wyróżnić kilka odmiennych kierunków przepływów kapitału właścicielskiego do systemu bankowego i czynników wpływu na te przepływy. W początkowym okresie transformacji występowała silna presja napływu kapitału zagranicznego do rosyjskiej bankowości, która była ograniczana przez formalne i nieformalne działania ze strony rządu i banku centralnego. Należy tu wspomnieć o ustalanych przez rząd limitach obec- 
ności kapitału zagranicznego w kapitale systemu bankowego w celu ochrony rodzimej bankowości przed zagraniczną konkurencją. Surowe procedury weryfikacji potencjalnych inwestorów zagranicznych przez bank centralny miały na celu ochronę rosyjskiej bankowości przed napływem kapitału spekulacyjnego oraz nadmiernym i niekontrolowanym dopuszczeniem do rynku usług bankowych wiarygodnych instytucji finansowych. Tendencja wzrostu udziału kapitału zagranicznego w rosyjskiej bankowości zatrzymała się w okresie kryzysu bankowego w 1998 r., kiedy kapitał zagraniczny w obawie przed stratami wycofywał się z Rosji. W latach 1999-2008 można zauważyć wzrost obecności kapitału zagranicznego, który został zatrzymany w okresie światowego kryzysu finansowego w efekcie wycofywania się kapitału z rynków wschodzących. W okresie 2009-2014 kapitał zagraniczny w kapitale własnym rosyjskiego sektora bankowego wyraźnie się umacniał, ale ten trend został przerwany przez sankcje gospodarcze zastosowane wobec Rosji przez Zachód w konsekwencji agresywnej polityki Rosji wobec Ukrainy i wojny rosyjsko-ukraińskiej. Od 2014 r. obserwuje się załamanie ekspansji nowych instytucji finansowych w rosyjskiej bankowości, a jednocześnie silne umocnienie pozycji banków z udziałem kapitału zagranicznego, szczególnie tych działających od dłuższego czasu na rynku rosyjskim i mocno już osadzonych w rosyjskim systemie bankowym. Banki te cieszą się wysoką wiarygodnością i są darzone zaufaniem klientów.

SŁoWA KLUCzowE: bankowość, kapitał zagraniczny, Rosja.

\section{Summary}

The aim of the article is to present the evolution of foreign capital presence in the banking system of Russia from the beginning of the transformation period to the beginning of the 20 s of the 21st century. The analysis shows that during the 30 years of these transformations in Russia, several different ownership capital flows into the banking system and factors influencing these flows can be highlighted. In the initial period of the transformation, there was a strong pressure on the inflow of foreign capital to the Russian banking sector, which was limited by formal and informal actions by the government and the central bank. The limits set by the government on the presence of foreign capital in the capital of the banking system in order to protect the domestic banking from foreign competition should also be mentioned. Strict procedures for the verification of potential foreign investors by the central bank were aimed at protecting Russian banking against the inflow of speculative capital and the excessive and uncontrolled admission of reliable financial institutions to the banking services market. The upward trend in the share of foreign capital in Russian banking stopped during the banking crisis in 1998, when foreign capital withdrew from Russian fearing losses.

In 1999-2008, an increase in the presence of foreign capital can be noticed, which was halted during the global financial crisis as a result of the withdrawal of capital from emerging markets.

In the period of 2009-2014, foreign capital in the equity of the Russian banking sector clearly strengthened, but this trend was interrupted by economic sanctions imposed 
on Russia by the West as a consequence of Russia's aggressive policy towards Ukraine and the Russian-Ukrainian war.

Since 2014, we have witnessed a collapse in the expansion of new financial institutions in the Russian banking sector, and at the same time a strong strengthening of the position of banks with foreign capital, especially those operating on the Russian market for a long time and already firmly embedded in the Russian banking system. These banks enjoy high credibility and are trusted by customers.

KEYWORDs: banking, foreign capital, Russia. 